\title{
Exploring Business English Talent Training Model under the Background of the Belt and Road Initiative
}

\author{
Guihang Guo ${ }^{1} \&$ Haimei Jin ${ }^{1}$ \\ ${ }^{1}$ School of English for International Business, Guangdong University of Foreign Studies, China \\ Correspondence: Guo Guihang, School of English for International Business, Guangdong University of Foreign \\ Studies, No.2 Baiyundadaobei, Guangzhou 510420, P.R. China. Tel: 0086-139-2242-3319. E-mail: \\ guihang@gdufs.edu.cn
}

Received: February 16, 2019

Accepted: March 7, 2019 Online Published: April 5, 2019

doi:10.5539/hes.v9n2p124

URL: https://doi.org/10.5539/hes.v9n2p124

\begin{abstract}
After thirty years of rapid development, China has become the second largest economy in the world. In order to strengthen economic cooperation with countries along the Belt and Road and assume more responsibilities as a major power, China has put forward the Belt and Road Initiative, which puts great pressure on the demand for Business English talents in society. However, at present, there is a shortage of high-level Business English talents in China. The traditional Business English talent training model cannot meet the needs of the business industry, which results in the serious disconnection between the cultivation of business talents and the market demand. Under the background of the Belt and Road Initiative, how to cultivate Business English talents has become a strategic issue. This research firstly combs the research of Business English talent training objectives and training model from the perspective of ESP Needs Analysis Theory, and then discusses the drawbacks of the current Business English training model from such aspects as curriculum setting, teaching system, and evaluation system, and gives suggestions in order to explore an appropriate Business English training model that meets the needs of the Belt and Road Initiative.
\end{abstract}

Key words: the Belt and Road Initiative, Business English, talent training model

\section{Introduction}

\subsection{Research Background}

The world today is undergoing complex and profound changes with the slow recovery of world economy. The international trade pattern and multilateral investment rules are brewing new adjustments. Countries are still facing serious development problems. Over the past 30 years, China's reform and opening up has made tremendous achievements, and China's international status has been increasing. Based on the concept of building a community of shared future for mankind and adapting to the development trend of globalization, President Xi Jinping therefore proposed the Belt and Road Initiative which aims at actively developing economic cooperation partnerships with countries along the Belt and Road, demonstrating the responsibility of a major power and letting the fruits of opening-up strategy benefit both Chinese people and people of the world.

The Business English subject has gradually emerged with the pace of reform and opening up and developed rapidly under the background of economic globalization. International trade has generated a great demand for compound Business English talents, which is the fundamental cause of the development of Business English subjects. In 2011, the Ministry of Education revised the Undergraduate Specialty Catalogue of Higher Institutions and officially included Business English in the catalogue. From 2012, colleges and universities can set up their own Business English subjects after being approved by the Provincial Education Department and registered by the Ministry of Education. This has greatly accelerated the development of Business English majors, and fully shows that the government and society have seen the development prospects and social needs of Business English majors (Wang, 2012). The continuous deepening of the Belt and Road Initiative and strengthening of international cooperation have not only promoted the vigorous development of China's international business trade activities, but also brought new opportunities and challenges to the development of Business English in China. For Business English talents training, the priority is to think about how to overcome some of the outstanding problems such as unreasonable Business English curriculum, outmoded teaching model, weak Business English teaching staff and figure out the current status of Business English talents training, and 
constantly optimize and improve the talent training model according to changing market demands. In this regard, the authors conduct the study in order to propose corresponding improvements.

\subsection{Research Significance}

The proposal of the Belt and Road Initiative is of great significance for promoting China's economic and trade cooperation with neighboring countries and enhancing China's international status. Its implementation requires the interaction of various links, of which the training of international business personnel is the essential. At present, China's international business personnel training has achieved certain achievements. Up to 2018, 367 colleges and universities across the country have set up Business English majors. However, there are also some problems following the continuous expansion of Business English disciplines and surge of the number of enrolled students. Looking at the current status of Business English talent training in China, it can be found that there is a far cry from demand criteria of the Belt and Road Initiative in terms of training path, curriculum setting, teaching system, and evaluation system and there is also an inconsistency between the actual talent requirements such as the professional knowledge about the laws, regulations and technical specifications of the neighboring countries. It has exerted tremendous pressure on the cultivation of compound international Business English talents. Therefore, exploring the Business English talent training model under the background of the Belt and Road Initiative has a strong practical significance for satisfying the talent demand of the initiative.

\subsection{Research Methods}

This paper starts with researching the needs of international Business English professionals under the background of the Belt and Road Initiative, summarizes the ideas of experts and scholars on the Business English talent training model, and analyzes the current drawbacks, aiming to give some targeted suggestions.

This research applies the literature research method. The literature research method refers to search for information from relevant monographs, papers, and newspapers according to a certain research purpose or subject, so as to fully understand the problems to be studied. Through the literature research method, researchers can understand the history and current status of research issues and therefore determine research goals. At the same time, researchers can obtain relatively realistic comparative data, which helps to grasp the whole picture of things (Yu, 2011). This study will firstly review the objectives of Business English personnel training, the development of training model and training strategy in order to provide theoretical references and practical solutions for the exploration of the Business English talent training model under the background of the Belt and Road Initiative.

\section{Literature Review}

\subsection{ESP Needs Analysis Theory}

The ESP, which emerged in the second half of the 20th century, was proposed by the famous linguists Halliday, Mclntosh, and Strevens in their co-authored Language Science and Language Teaching.

ESP is the abbreviation for English for Specific Purpose. It aims to teach students English in a specific field or industry, therefore, it is specialized, purposeful and pertinent. The British applied linguist Strevens (1988) pointed out four fundamental characteristics of the ESP curriculum: First, it must meet the learners' specific needs; second, its contents are related to the specific occupations; third, as for syntax, vocabulary, semantics, and discourse analysis, the emphasis must be placed on the use of language related to specific professions; fourth, it contrasts with ordinary English. Different ESP courses cover the professional knowledge of different disciplines. In foreign countries, Business English as an important branch of ESP has been set as an independent discipline, and because of the importance and effectiveness of Business English applications, foreign countries pay more attention to Business English teaching methods and teaching materials, and have achieved a lot. As a result, the current overseas Business English teaching is very mature. However, for the study of Business English talent training mode, there is no scientific theory system at home and abroad.

Need Analysis refers to the techniques and methods for studying the needs of the research subjects through introspection, interviews, observations, and questionnaires. Long (2005) believes that there is a close relationship between Need Analysis and ESP, and Need Analysis has an important guiding role in second language learning. Hutchinson \& Waters divided "need" into "target need" and "learning need". The "target need" is the purpose and motivation of the learner; the "learning need" refers to the language basis and language ability required by the learner in the future. ESP takes Need Analysis theory as the standpoint of its talent training model design, as it tries to understand students' learning objectives and learning process from their needs and then optimize the ESP curriculum, improve the teaching system, and build a scientific personnel training evaluation system. 


\subsection{Business English Talent Training Objectives}

China's higher education has entered the popularization stage. The concept of marketization of higher education is also firmly rooted in people's minds. The university must grasp the initiative for development in the competition and form its own characteristics and advantages (Zhuang, 2017). Although the current labor market has a strong demand for Business English talents, for any particular institution, if its talent training objective is not clear and distinctive, it will not only affect the construction and effect of talent cultivation, but also influence the long-term development of the Business English major.

The Business English major is set for the sake of China's higher education's adapting to the development of the times, satisfying the needs of the society and the market, and is an organic unity of international business education and English language education (Chen, 2016). In 2009, the Ministry of Education clearly stated the goal of Business English talent training in the Teaching Requirements for BA Programs in Business English, that is, the students should become interdisciplinary talents who have a solid foundation in English and a broad international vision, and can master the basic knowledge and theory of economics, management, law, and other related disciplines. They should also possess humanistic qualities and cross-cultural communication abilities, and can engage in jobs such as business, economics, trade, management, finance, foreign affairs in international environment. The regulations of the Ministry of Education have pointed out the direction for the construction of Business English majors in high education. Regarding the connotation of interdisciplinary talents, the academic circles have different opinions. Du (1997) believes that "interdisciplinary talents refer to a compound talent who not only masters a variety of foreign language skills, but also has basic knowledge and skills of other disciplines". Dai (1999) mentioned in his article that "from the perspective of a foreign language, interdisciplinary talents mainly refer to those who have mastered two professional and practical skills".

Business English professionals should meet high standards in basic English skills, general knowledge, relevant professional knowledge and skills, and comprehensive ability and quality. In general, Business English talent training goals can be divided into applied talents, compound talents, international talents and innovative talents. Firstly, there are currently 367 universities and colleges offering Business English majors in China. Except for the University of International Business and Economics, all other universities are local colleges, and most colleges and universities are classified as application-oriented university. If vocational universities are included, there are more than 2,000 colleges and universities opening Business English majors in China. According to the functional division and teaching requirement of various institutions, it is indicated that "applied" is the chief feature of Business English professionals and the primary goal of personnel training (Zhuang, 2017). Secondly, the National Education Department's Some Opinions on the Education Reform of Foreign Language Specialization for the 21st Century proposes the training of interdisciplinary talents, that is, the combination of foreign language and other related disciplines, and points out that this type of compound foreign language professionals are the requirements of both the socialist market economy and the new era. Economic globalization and China's continuous deepening of reform and opening up have determined the "interdisciplinary" of English teaching and especially the integration with economic and trade disciplines (Hu, 2010). Thirdly, Prof. Yang Fujia, the academician of the Chinese Academy of Sciences and president of the University of Nottingham, UK, said in an interview in 2011 that the internationalization of higher education is to cultivate first-rate talents who can integrate the eastern and western cultures and better serve the interests of their respective countries. The objectives of Business English talent training fully reflect the goal of internationalization of China's higher education. Combining theoretical research with the actual situation of Business English talent training, the cultivation of internationalized Business English talents mainly includes international awareness, knowledge and capabilities. Fourthly, the cultivation of innovative talents emphasizes the development of individual personality. For many years, the instrumentality of English language has been deeply ingrained in English education. As a result, the training of language knowledge and language skills has been overemphasized in the teaching process, and English majors lack the ability to think independently. Since the establishment of the Business English major, many colleges and universities still adopt the traditional English teaching methods, ignoring students' ability to solve practical problems. The biggest feature of business activities lies in its "complexity", which requires the innovation of the training model in order to help students deal with a variety of unpredictable and complex issues.

\subsection{Business English Talent Training Models}

After many years of exploration, Business English training model has gradually become clear and showed a diversified trend. Training models vary widely among different institutions and can be roughly divided into four types (Zhang, 2012). The first is the "English + Business knowledge" model. That is, a small number of Business English courses, such as Business English, foreign trade correspondence and so on are added in basic English 
courses such as listening, speaking, reading, writing, and translating, The second is "Business English" model. A series of Business English courses are set up, such as Business Negotiation English, International Trade Practice English. The third type is the "English + Business Course in Chinese" model. In addition to the basic English courses, Chinese business courses are listed. Business professionals are invited to teach and students can learn more systematic business knowledge. The fourth mode is "English + Business-oriented English", which is essentially a dual major course. Examining these four modes will reveal: First, the four modes have their own shortcomings. The first is old and can no longer meet the need of the Belt and Road Initiative. The second is relatively avant-garde. At present, there are few institutions that can provide such faculty in China. The third has split English and business knowledge. The fourth may result in the lack of emphasis and deepening of business knowledge. Second, there are still some gaps between curriculum setting and implementation of personnel training goals. It should be pointed out that at present, the subjects of these four types of training are mainly undergraduate students. Although some universities also enroll non-English majors to pursue the master's degree, it is not a mature foreign language talent training model after all. It requires us to deeply reflect and discuss how to cultivate high, fine and advanced professional interdisciplinary foreign language talents in the postgraduate and doctoral studies.

\section{Exploring Business English Talent Training Model under the Background of the Belt and Road Initiative}

\subsection{Drawbacks of the Business English Talent Training Model}

In regard to talents training, most colleges and universities have not designed corresponding talent training models based on different orientations and this is because the overall teaching philosophy and teaching activities have not yet shaken off the old-fashioned model of English language teaching. The train model and objectives are seriously mismatched. The problems of the current Business English talent training model mainly lie in the curriculum setting, teaching system and talent training evaluation system.

\subsubsection{Imperfect Curriculum Setting}

Teaching Requirements for BA Programs in Business English has designed a curriculum system for Business English majors and it covers three modules which are language knowledge and skills, business knowledge and skills and humanistic quality respectively (Chen \& Wang, 2009). However, in the process of implementation, most institutions cannot meet the requirements, mainly reflected in the following four aspects:

(1) The number of faculty is insufficient. Due to the lack of adequate Business English faculty, many Business courses cannot be taught in English. In addition, as most English teachers are not proficient in business knowledge, their teaching methods are limited to language training, which splits the organic relationship between business and English.

(2) The proportion of General English classes is too large. Most colleges and universities still attach great importance to language training, and ignore business courses. This leads to a lack of systematic business knowledge of students, which is not good for their competitiveness after graduation.

(3) There are too few practical courses. Most institutions have not taken practical courses into account, partly due to the lack of practice platform. The ignorance is not conductive for the cultivation of Business English majors' application and innovation ability.

(4) The humanities education courses are not comprehensive enough. Most institutions do not offer courses that analyze the status of world affairs and introduce the politics, religion and culture about the countries along the Belt and Road. Without a comprehensive understanding of other civilizations, the cultivation of Business English professionals cannot achieve the objective of "internationalization".

\subsubsection{Outdated Teaching System}

The problems of the teaching system mainly include the following aspects:

(1) Obsolete teaching methods. Teaching Requirements for BA Programs in Business English proposed that Business English teaching should be student-centered and teacher-oriented, and focus on cultivating students' learning abilities, research abilities, and problem-solving abilities. However, due to the long-term effects of traditional teaching methods, it is difficult to truly form a teaching method that is "student-centered" in the entire teaching system.

(2) Unscientific teaching materials. At present, no professional Business English teaching materials have been unanimously recognized in the industry. Textbooks generally lack hierarchy, comprehensiveness and universality. Current textbooks either emphasize too much on language knowledge, ignore the gradual deepening of business 
knowledge, or only consider the business content, ignoring the complementarity with language. It has hindered the development of students' interdisciplinary ability.

(3) Single evaluation standards. Written examination is still the main evaluation tool while students' ability to solve practical problems is neglected. This makes teachers and students pay too much attention to theoretical knowledge and weakens the flexible use of knowledge.

\subsubsection{Incomplete Evaluation System}

At present, the main evaluation mechanism for a subject is the assessment of the institution, which is relatively simple. Over the years, our country's evaluation of universities has mainly come from the evaluation results of administrative organizations at all levels, in which quantified data have been attached too much importance while talent training has been seriously neglected. For Business English subject that aims at cultivating "applied, interdisciplinary, international and innovative" personnel, it is necessary to incorporate an evaluation system that can comprehensively show the effectiveness and status of talent training in different colleges and universities.

\subsection{Reform of Business English Talent Training Model}

\subsubsection{Optimizing the Curriculum Setting}

The curriculum setting plays an important role in the construction of the talent training model. The curriculum setting can be seen as a concrete embodiment of the talent training model, and it is also the fundamental way to achieve Business English talent training objectives. On the whole, the curriculum setting of most colleges and universities across the country cannot meet the social demand for interdisciplinary talents with a global perspective, high humanistic qualities, and an innovative spirit. Thus, the curriculum setting should be improved from the following aspects:

(1) Improving faculty construction. A high-quality teacher team is an important guarantee for cultivating compound and applied Business English talents. A Business English teacher should possess a solid knowledge of both English language and business in order to meet the "dual-qualified" criteria set by the Ministry of Education (Wang, 2007).

(2) Setting up a language course that closely combines English and business. In terms of language courses in the basic stage, it is not appropriate to separate the language and business knowledge. It is necessary to upgrade pure language training and promise the application of business knowledge at the same time. The degree of difficulty should be progressively increased.

(3) Increasing the amount of practical courses. Practical courses not only can be added in compulsory courses as a component, but also can be set up separately. Students should leave the classroom, conduct field studies in enterprises, and write a report so that the effectiveness can be tested.

(4) Enriching the content of elective courses. The talent training objectives of "internationalization" and "innovative" cannot be achieved only through the provision of specialized courses. In order to meet the demands for various and versatile talents of the Belt and Road initiative, courses related to introduction about the countries along the Belt and Road and current international trade should be increased. Moreover, courses like international accounting, international business law and so on can be considered to provide students with a rich reserve of knowledge in different professional fields.

\subsubsection{Improving the Teaching System}

The reform of Business English teaching system can be carried out from the following aspects:

(1) Fostering a learner-centered teaching philosophy. Teaching activities emphasize the output of language and the cultivation of communicative competence, which manifest as student-centered, task-oriented and following an open path to reach the established goals (Zeng, 2002). The purpose of Business English teaching is to cultivate the students' ability to use English in specific business fields. In the teaching environment, teachers and students should be encouraged to jointly organize tasks and activities and be placed in a language communication teaching environment.

(2) Unifying teaching materials. Scientific and systematic teaching materials can optimize the teaching effect and ensure that students gradually construct knowledge system of "English + Business". Currently, there is a lack of specialized Business English textbooks. The textbook publisher shall organize experts to compile teaching materials according to the requirements for Business English talent training and teaching instructions in Teaching Requirements for BA Programs in Business English.

(3) Standardizing the curriculum evaluation system. Written examination should not be taken as the main 
evaluation toll, students' classroom performance and their reports in the practical courses as mentioned above should be listed as an important part of the final assessment.

\subsubsection{Constructing a Scientific Talent Training Evaluation System}

In order to guarantee the quality of talent training, the State Council's Outline for Medium and Long-Term Education Reform and Development Plan (2010-2020) clearly states that the education quality evaluation shall be carried out by governments, schools, parents and all sectors of society (Zhuang, 2017). In September 2011, the Ministry of Education proposed the establishment of a third-party assessment system of talent training quality with the participation of interested party. The establishment of a third-party evaluation system for talent training is an important measure to strengthen the monitoring of teaching quality and is conducive to promoting teaching reform and meeting the development needs of higher education in the context of the Belt and Road Initiative. Business English talent training aims at cultivating "applied, interdisciplinary, international and innovative" talents. Whether or not it achieves the aim must be considered from the perspectives of employers, students and society. Institutions should set up such third-party evaluation agencies in conjunction with relevant social departments so that their teaching quality can be evaluated fairly.

\section{Conclusion}

Under the background of the Belt and Road Initiative, how to cultivate international Business English talents that meet social demands is an issue that must be considered. The priority is to clarify the training objectives. Business English talent training is to cultivate "applied, interdisciplinary, international and innovative" talents. With the guidance of training objectives, it is found that there exists some shortcomings in the current Business English talent training models in terms of curriculum setting, teaching system and evaluation system of talent training. The author conducts a detailed analysis from the perspective of ESP Need Analysis theory and offers targeted suggestion such as increasing the amount of practical courses, fostering a learner-centered teaching philosophy and establishing a third-party evaluation system for talent training, hoping to offer beneficial references for the reform of Business English talent training models in the context of the Belt and Road Initiative.

\section{Acknowledgments}

This research was supported with funds from Guangdong University of Foreign Studies under the provincial research project of the Career Development Strategies and Practices for Business English Teachers Under the Guide of National Criteria for Teaching Quality of Undergraduate Programs (No.2018220). The support is gratefully acknowledged.

\section{References}

Chen, F. (2016). Thoughts on the Training Objectives of Business English Talents. Henan: Journal of Henan Institute of Education (Philosophy and Social Sciences Edition).

Chen, Z. M., \& Wang, L. F. (2009). Teaching Requirements for BA Programs in Business English. Beijing: Higher Education Press.

Dai, W. D. (1999). Some Thoughts on the Strategies for Cultivating High-quality Interdisciplinary Foreign Language Talents in the 21st Century. Foreign Language World, 4, 1-3.

Du, R. Q. (1997). Practice of Cultivating Interdisciplinary Foreign Language Talents. Foreign Language Education, 2, 33-36.

Hu, K. B. (2010). Training English Majors with Two or More Specialized Expertises, Innovative Consciousness and International Vision: Theoretic Consideration and Practice. Foreign Languages in China, 6, 8-16.

Long, M. H. (2005). Second Language Needs Analysis. London: Cambridge University Press. https://doi.org/10.1017/CBO9780511667299

Strevens, P. (1988). ESP: State of the Art. Singapore: SEAMEO Regional Language Centre.

The National Foreign Language Teaching Advisory Board under the Ministry of Education (2000). Some Opinions on the Education Reform of Foreign Language Specialization for the 21st Century. Beijing: Foreign Language Teaching and Research Press.

Wang, L. F. (2012). Repositioning the Discipline and Academic Research of Business Foreign Languages. Foreign Languages in China, 3, 4-9.

Wang, X. L. (2007). On the Training Mode of Business English Majors with Compound Applied Talents. Science and Technology Innovation Herald, 33, 230-231. 
Yu, Y. (2011). The Construction of Employment-oriented Professional Training System in Business Major-A Case Study of Jiangsu Municipal Vocational College. Suzhou University.

Zeng, W. X. (2003). Implementation of Business English Teaching. Journal of Henan Institute of Education (Philosophy and Social Sciences), 22(1), 119-121.

Zhang, X. W. (2012). Research on the Training Mode of Compound Foreign Language Talents. Science \& Technology Vision, 36, 31.

Zhuang, Y. L. (2017). Research on the cultivation and teaching reform of Business English talents. Beijing: Beijing Institute of Technology Press.

\section{Copyrights}

Copyright for this article is retained by the author(s), with first publication rights granted to the journal.

This is an open-access article distributed under the terms and conditions of the Creative Commons Attribution license (http://creativecommons.org/licenses/by/4.0/). 